\title{
Justice, Legitimacy and the Authority of Legislation within the European Union
}

\author{
Abstract
}

What are we to make of the authority of legislation within the EU? Many EU lawyers have questioned the significance of legislative decision-making within the EU. This article challenges these views and argues that the EU legislature must enjoy adequate freedom to shape EU law with the general interest in mind. Institutional accounts that seek to curtail the authority of legislation tend to rest upon 'content-dependent' conceptions of political legitimacy, according to which the legitimacy of a decision depends on its moral qualities. I challenge such conceptions, as they overlook our reasonable disagreements on justice and rest upon an overly optimistic (pessimistic) view of the Court (the legislature), and argue for a content-independent conception of legitimacy, following which the benefits of legislative decision-making are more easily understood. The authority of legislation deserves wider recognition among EU lawyers for reasons of political legitimacy and because the EU legislature is better positioned to decide in the general interest.

Keywords

EU legislature, justice, legitimacy, reasonable disagreement, institutional fallibility

\section{Introduction}

The European Union legislature has been extremely prolific. Its legislative acts are vast in number and scope, regulating most domains of EU law these days. That raises the question of what we are to make of that institution and to what extent we should value its decisions. Some EU lawyers question the significance of legislative decision-making and find it unproblematic if the Court of Justice of the European Union (CJEU or Court) undermines its authority. Francis Jacobs, a former Advocate General (AG) at the Court, named it the 'European way' that 'many fundamental choices for society are now made, and probably have to be made, not by the legislature, not by the executive, but by the courts'. ${ }^{1}$ This position appears indicative of what a considerable group EU lawyers think of legislatures and legislation. For example, Charlotte O’Brien has asserted that 'judicial decisions and intellectual commentary, not legislation, have transformed conceptions of human rights and democracy', ${ }^{2}$ even

\footnotetext{
${ }^{1}$ Francis Geoffrey Jacobs, The Sovereignty of Law: The European Way (Cambridge University Press 2007$) 1$.

2 Charlotte O’Brien, 'I Trade, Therefore I Am: Legal Personhood in the European Union' (2013) 50 Common Market Law Review 1643, 1680.
} 
though there is little empirical evidence that supports this. ${ }^{3}$ Going even further, Floris de Witte has made the argument that the EU must contain national legislative processes by re-allocating responsibilities 'to a different type of government, whether judicial ... expert based ... administrative ... or the individual'. ${ }^{4}$ The EU's course of action, apparently, is to be decided any institution but the legislature.

In this article, I offer an alternative view that emphasises the benefits of legislative decisionmaking within the European Union. I shall argue that the EU legislature must enjoy adequate freedom to shape EU law with the general interest in mind. This argument rests upon an account of legitimate EU political institutions, different from that underlying the more dismissive views on legislative authority above. Popular among EU lawyers are so-called 'content-dependent' or 'instrumentalist' theories on legitimate political authority, ${ }^{5}$ according to which the legitimacy of a decision depends on its moral qualities. The EU legislature, it is important to clarify immediately, is negatively affected by such instrumentality. If the authority enjoying legitimacy is that which realises the best substantive outcomes, legislation becomes the baseline, which we treat as legitimate unless we can conceive of better outcomes. Those legislative decisions that we like are authoritative, while others are ready for a second round of debate in court. ${ }^{6}$ I shall demonstrate the shortcomings of such theories of legitimate authority and argue for a content-independent conception of legitimacy, following which the benefits of legislative decision-making are more easily understood.

Section 1 uses a concrete example from EU citizenship law to demonstrate that one of the problems of instrumentalism is that it leads us to take wholly inconsistent positions on institutional questions, such as the interpretation of legislation and rule-following. Turning to recent literature on social justice within the EU, section 2 highlights the commonality of instrumental conceptions of legitimacy in EU scholarship and uncovers the two core assumptions underlying such conceptions. These assume that (1) we can come to a shared understanding of justice and the common good and

\footnotetext{
${ }^{3}$ That lawyers tend to be overly optimistic about what can be and has been realised by judicial decision-making is something political theorists have emphasized on multiple occasions. Robert A Dahl, Democracy and Its Critics (Yale University Press 1991); Thomas Christiano, 'An Instrumental Argument for a Human Right to Democracy' (2011) 39 Philosophy \& Public Affairs 142. See also, Ran Hirschl, Towards Juristocracy: The Origins and Consequences of the New Constitutionalism (Harvard Univ Press 2007).

${ }^{4}$ Floris de Witte, 'Sex, Drugs \& EU Law: The Recognition of Moral and Ethical Diversity in EU Law' (2013) 50 Common Market Law Review 1545, 1554 (footnotes omitted).

${ }^{5}$ For a critical discussion of instrumentalism, read Thomas Christiano, 'The Authority of Democracy' (2004) 12 Journal of Political Philosophy 266.

${ }^{6}$ For a proponent of continued debate in Court, Miguel Poiares Maduro, 'Interpreting European Law - Judicial Adjudication in a Context of Constitutional Pluralism' (2008) 1 European Journal of Legal Studies 11.
} 
(2) that the judiciary is more likely to produce desirable outcomes. Section 3 establishes that the first is implausible because it overlooks our reasonable disagreements on justice. Section 4 rejects the second, for resting upon an overly optimistic (pessimistic) view of the CJEU (the legislature). I argue in section 5, that the authority of legislation deserves wider recognition among EU lawyers for reasons of political legitimacy and because of the EU legislature's specific institutional abilities. Section 6 offers a response to two final arguments EU lawyers may bring against my claim that the authority of legislation deserves better recognition. Against those who claim that the EU's hierarchy of legal sources demands the Court to police the legislature strictly and that legislation is not always of adequate quality, I shall respond that existing shortcomings may be the consequence of us not giving the EU legislature sufficient freedom to amend legislation.

\section{Instrumentality as a vote of no confidence in the EU legislature}

Instrumentalist perspectives on legitimate authority are common in EU law scholarship. This section offers three examples of such instrumentalism in EU legal scholarship: the Dano and Alimanovic cases and recent scholarship on justice within the EU, all of which conflates legitimacy with justice; inconsistent perspectives on legislative interpretation; and ...

Much ink has been spilled over Dano and Alimanovic and I will not discuss them in detail. ${ }^{7}$ Rather, I will use them as an illustration of the predominance of instrumentalism. Ms Dano, a Romanian national, entered Germany together with her child in 2010, where she lived with her sister, who took care of both. Ms Dano made applications for jobseeker benefits in 2011 and 2012, both of which the German authorities rejected. ${ }^{8}$ The responsible authorities took a similar decision in the case of Ms Alimanovic and her children, even though their situation differed from that of Ms Dano in important respects. The latter, we were told by the CJEU, did not demonstrate signs of integration within Germany, ${ }^{9}$ while the Alimanovic family had resided in Germany before and two members of the family had been in employment for a period of 11 months - from June 2010 until May $2011 .^{10}$ Notwithstanding this difference, the CJEU decided in both cases that Germany's denial of benefits was compatible with EU law.

\footnotetext{
7 For excellent discussions of these decisions, read: Niamh Nic Shuibhne, "“What I Tell You Three Times Is True” Lawful Residence and Equal Treatment after Dano' (2016) 23 Maastricht Journal of European and Comparative Law 908; Daniel Thym, 'The Elusive Limits of Solidarity: Residence Rights of and Social Benefits for Economically Inactive Union Citizens' (2015) 52 Common Market Law Review 17; Verschueren (n 13).

${ }^{8}$ Case C-333/13 Dano, ECLI:EU:C:2014:2358, paras 35-41

${ }^{9}$ Ibid, para 39.

${ }^{10}$ Case C-67/14 Alimanovic, ECLI:EU:C:2015:597, paras 25-32.
} 
Both cases raise questions of social justice - what should have been due to the claimants? and according to three recent accounts of social justice within the EU, justice was denied to the applicants. De Witte argues that Dano violates his communitarian principles, according to which EU citizens cannot be denied benefits that 'prevent human need'. ${ }^{11}$ And since the function of subsistence benefits such as those claimed by Ms Dano is aiding those in need and 'must be extended to all legally resident citizens, regardless of economic status, nationality, or engagement with the labour market in the host state'. ${ }^{12}$ Neuvonen adopts a more egalitarian angle and claims that Dano offers an illustrative example of the structural equality problem in EU law. ${ }^{13}$ O'Brien has offered the most damning assessment of both cases, alleging that they have created 'a moral vacuum within the free movement framework'. ${ }^{14}$

All three accounts are instrumentalist in nature, for they effectively suggest that the legitimacy of EU political acts depends on the substantive results, from which it follows that the authority of legislation can be circumvented if a more just outcome (in their view) is realised. De Witte and Neuvonen acknowledge explicitly that Dano produces an outcome compatible with the relevant legislative rules. ${ }^{15}$ Their argument that the case is wrongly decided thus implies that the CJEU should have ignored those rules. That Alimanovic implemented the Directive is even harder to dispute, because its text offered great clarity about the intended result. Ms Alimanovic and her daughter had worked in temporary jobs for less than a year. As a consequence, they did not fall within the scope of Article 7(3)(b) of the Citizenship Directive, according to which

a Union citizen who is no longer a worker or self-employed person shall retain the status of worker or selfemployed person [when] he/she is in duly recorded involuntary unemployment after having been employed for more than one year and has registered as a job-seeker with the relevant employment office

\footnotetext{
${ }^{11}$ n 12 above, 232.

12 ibid 155.

${ }^{13}$ Päivi Johanna Neuvonen, Equal Citizenship and Its Limits in EU Law: We The Burden (Hart Publishing 2016) chapter 2.

${ }^{15}$ De Witte believes that ' $[b] y$ refusing basic provisions benefits to persons who come to Germany solely in order to benefit from the social assistance system of that Member State and who do not seek in any way to integrate themselves into the labour market, the national legislation is consistent, in my view, with the EU legislature's intention'. de Witte (n 12) 152. Neuvonen objects that Dano consists of a mere application of the Directive, while the Court should, in her view, have assessed the Directive in the light of the Treaties. This is to accept, of course, that based on a reading of the Citizenship Directive alone, the right outcome was the one reached by the CJEU. Neuvonen (n 29) 60-61.
} 
They were covered by Article 7(3)(c) of the Directive, on the other hand, which provides those having completed fixed-term employment for less than a year with the right to retain the status of worker for no less than six months if in duly involuntary unemployment. It was beyond dispute, however, that Ms Alimanovic no longer enjoyed the status under this provision when they claimed benefits. ${ }^{16}$ Despite not being within the scope of that provision, the family derived a right to reside in Germany from Article 14(4)(b). According to this provision, Union citizens 'may not be expelled for as long as the Union citizens can provide evidence that they are continuing to seek employment and that they have a genuine chance of being engaged'. But since Article 24(2) of the Directive allows Member States to deny benefits to those falling within the scope of the Article 14(4)(b), ${ }^{17}$ Germany was permitted to deny the family benefits. ${ }^{18}$ The decision makes perfect sense when the Directive's text is considered.

A closely related question concerns the central purpose of legislative interpretation. On a content-independent account of legitimate political institutions, not conditional on some measure of justice, but instead on the fairness of the decision-making process by which we resolve our disputes, we would take the task of legal interpretation to be about ascertaining the envisioned meaning and intended consequences of the legal norm that is interpreted. EU lawyers preferred theory of interpretation, however, frequently is instrumentalist and depends on their conception of justice.

In recent decisions on access to social assistance, the Court deferred to the Directive's written rules and permitted the Member States to deny social assistance to citizens who had not satisfied the prescribed temporal requirements. ${ }^{19}$ These decisions were criticised for failing to realise the substantive purposes behind the legislation. As one of these purposes is preventing EU citizens from becoming an unreasonable burden on the social assistance system of the host Member State, ${ }^{20}$ the Court should not have considered solely EU citizens' period of legal residence, but also their individual circumstances for a proper assessment of the (un)reasonableness of the burden. ${ }^{21}$ Besides the right to social assistance entitlements, however, also EU citizens' protection against expulsion from the host

\footnotetext{
${ }^{16}$ n 19 above, para 55.

17 Ibid para 57.

${ }^{18}$ According to Article 24(2) of the Directive, by way of derogation from the principle of equal treatment, 'the host Member State shall not be obliged to confer entitlement to social assistance during ... the longer period provided for in Article 14(4)(b)'.

19

20

${ }^{21}$ It did so in Case C-67/14 Alimanovic, ECLI:EU:C:2015:597 and Case C-299/14 García-Nieto, ECLI:EU:C:2016:114. For such criticism, read: Herwig Verschueren, 'Preventing "Benefit Tourism" in the EU: A Narrow or Broad Interpretation of the Possibilities Offered by the ECJ in Dano?' (2015) 52 Common Market Law Review 363; Charlotte O'Brien, 'Civis Capitalist Sum: Class as the New Guiding Principle of EU Free Movement Rights' (2016) 53 Common Market Law Review 937.
} 
Member States is conditional upon their period of residence there. Citizens with residence rights of a period shorter than five years can be expelled on grounds of public policy and security, while those with permanent residence (five years of continuous residence) cannot be expelled 'except on serious grounds of public policy or public security'. ${ }^{22}$ No expulsion measures may be taken to those who have been resident for more than ten years, 'except if the decision is based on imperative grounds of public security'. ${ }^{23}$ Interpreting these provisions, the Court displaced the written rules that condition protection against expulsion upon the citizen's period of residence in the host state. Invoking the Directive's recitals, the Court decided that the level of protection depends on the citizens' personal qualitative circumstances, thereby weakening the protections enjoyed by long-term residents. ${ }^{24}$ Displeased with that result, scholars this time took the position that the Court should not have examined the substantive purposes behind the rule, but have deferred to the Directive's written rules. ${ }^{25}$

Significantly, it is not just that different authors have coincidentally opted for different methods of interpretation in different situations. The same scholars have taken opposite positions. Eleanor Spaventa held, on the one hand, that 'there is not much to be said in favour' of those decisions that clarify 'that those Union citizens who do not satisfy the black letter conditions contained in the Directive, ${ }^{26}$ but also criticised the individual assessments introduced by the expulsion case law for introducing elements incompatible with the text of the Directive. ${ }^{27}$ Niamh Nic Shuibhne, moreover, has lamented the social assistance case law for radically downgrading 'the formerly central place of individual assessments', ${ }^{28}$ but argues that the expulsion case law limits rights 'in disruption of the will of the legislature'. ${ }^{29}$ Apparently, whether the text of the Citizenship Directive must be leading and constrain the judges, and the written rules to be applied, depends on the circumstances of the case. The CJEU must be either purposivist or textualist, depending on the result.

\footnotetext{
${ }^{22}$ Article 28(2) of Directive 2004/38/EC.

${ }^{23}$ Article $28(3)$ of Directive 2004/38/EC.

${ }^{24}$ Case C-378/12 Onuekwere ECLI:EU:C:2014:13 and Case C-400/12 M.G., ECLI:EU:C:2014:9.

${ }^{25}$ Stephen Coutts, 'Union Citizenship as Probationary Citizenship: Onuekwere ' (2015) 52 Common Market Law Review 531; Dimitry Kochenov and Uladzislau Belavusau, 'Kirchberg Dispensing the Punishment: Inflicting "Civil Death" on Prisoners in Onuekwere (C-378/12) and M.G. (C-400/12)' (2016) 41 European Law Review; Dora Kostakopoulou, 'When EU Citizens Become Foreigners' (2014) 20 European Law Journal 447.

${ }^{26}$ Eleanor Spaventa, 'Once a Foreigner Always a Foreigner: Who Does Not Belong Here Anymore? Expulsion Measures', Residence, Employment and Social Rights of Mobile Persons: On How EU Law Defines Where They Belong (Intersentia 2016) 96 (italics added).

27 ibid 105-106.

${ }^{28}$ Niamh Nic Shuibhne, 'Limits Rising, Duties Ascending: The Changing Legal Shape of Union Citizenship' (2015) 52 Common Market Law Review 889, 913.

29 ibid 921 (italics omitted).
} 
A similar tendency affects debate on the relationship between primary and secondary EU law. If a more desirable result is realised by interpreting legislation in light of the Treaties, EU scholars are inclined to approve of such 'harmonious interpretation', ${ }^{30}$ but whenever such reasoning leads to results that are incompatible with out preferred substantive results, the legislative provisions should have been respected. This seems to explain why

It is difficult to believe that such instrumentalist approaches to authority and the subsequent belief that it is legitimate for the judiciary to overrule legislative decisions in the name of justice do not also signal a vote of no confidence in legislatures. After all, if we have no confidence that the reviewer will do a better job than the reviewed, ${ }^{31}$ our position that the judiciary is to debate again important questions of public morality and policy, as settled already by legislation, is simply untenable. As we could see in the introduction to this article, de Witte and O’Brien have also explicitly made the case against legislative decision-making. Two assumptions reinforce that position, which Bellamy described as the core tenets of legal constitutionalist thought: first, we can rationally agree on the kind of substantive outcomes political decision-makers must realise and, secondly, the judicial process can more steadfastly achieve these results. ${ }^{32}$ Much of the debate on justice within the EU takes place against these background assumptions. To understand the problem of instrumentalist theories, we should realise the difficulties underlying these assumptions. The next two sections explore these.

\section{Reasonable disagreement}

An instrumentalist theory of legitimate institutions considers the exercise of authority legitimate when just. That suggests that the possibility exists for us to define the requirements of justice and possibly even that we can come to agree on what that discovery entails. As one prominent contributor to the debate on justice within the EU claimed, 'human rights possess sufficient normative substance and legal appreciation together with sufficient commonality and sufficient moral weight to acquire support

30

${ }^{31}$ Neil K Komesar, Imperfect Alternatives: Choosing Institutions in Law, Economics and Public Policy (University of Chicago Press 1997) 207.

32 Richard Bellamy, Political Constitutionalism: A Republican Defence of the Constitutionality of Democracy (Cambridge University Press 2007) 20. 
amongst the people' and, therefore, enjoy 'reasonable normative stability'. ${ }^{33}$ That position, however, is implausible. Disagreement simply is too persistent a fact of our political lives and happens against a background in which it seems unrealistic to think that correct moral truths are identifiable. ${ }^{34}$ As Waldron explained, this is not necessarily because uniformly valid morals are non-existing, but because no one seems capable of their discovery. ${ }^{35}$ Equally important, people generally disagree not because of self-interested or malign motives, but because of what Rawls called 'the burdens of judgment'. ${ }^{36}$ Individuals have disparate interests and substantive moral beliefs, which are largely informed by our different experiences in life, the specific social conditions we grew up under, and the diverse sets of talent we possess. These different conditions shape our preferences and sense of justice, and contribute to disagreement about the ends to be pursued by politics. In addition, often we lack the ability to develop as good an understanding of the needs and desires of other persons when compared to our awareness of our own. Such cognitive bias increases the chance of moral fallibility in our understanding of other persons. ${ }^{37}$ Some of us may be driven by malicious ambitions, but it appears implausible to think that this is true for the great majority of us. Disagreements on the good, therefore, are better considered as reasonable disagreements among reasonable people.

Such disagreements extend beyond the confines of the state and equally affect transnational policy-making. This is not to say that EU lawyers have exaggerated the importance of respecting rights and principles of justice. The great majority of individuals living in this world share the belief that the protection of individual rights merits serious attention, but the precise import of rights raises grave disputes. Recent controversies over the precise requirements of gender equality and the economic right to freely conduct a business demonstrate the prematurity of speaking of a reasonable stability of rights within the EU. ${ }^{38}$ Likewise, most people expect the EU to uphold principles of justice and yet

\footnotetext{
${ }^{33}$ Andrew J Williams, The Ethos of Europe: Values, Law and Justice in the EU (Cambridge University Press 2010) 321322.

${ }^{34}$ Dahl (n 3 above) 66.

${ }^{35}$ Waldron, Law and Disagreement (n 22) Chapter 8.

${ }^{36}$ John Rawls, Political Liberalism (Columbia University Press 1993) 54-58.

${ }^{37}$ Thomas Christiano, The Constitution of Equality: Democratic Authority and Its Limits (Oxford University Press 2008) Chapter 2. A strong assumption underlying the case for democracy, as Dahl explained, is that 'no person is, in general, more likely than yourself to be a better judge of your own good or interest or to act to bring it about'. Dahl (n 3) 99. ${ }^{38}$ On gender equality, Case C-236/09 Test-Achats, ECLI:EU:C:2011:100. For a useful analysis, JHH Weiler, 'Epilogue: Judging the Judges - Apology and Critique' in Maurice Adams and others (eds), Judging Europe's Judges: The Legitimacy of the Case Law of the European Court of Justice (Hart 2013) 242-244. On the right to freedom to conduct business, Case C-426/11, Alemo-Herron, ECLI:EU:C:2013:521; Case C-157/15, G4S, ECLI:EU:C:2017:203. An interesting analysis of Alemo-Herron has been offered by Eduardo Gill-Pedro, 'Freedom to Conduct Business in EU Law: Freedom from Interference or Freedom from Domination?' (2017) 9 European Journal of Legal Studies.
} 
there is no consensus on what it means for the EU to act accordingly. For example, there is no agreed upon understanding of how principles of justice bear upon claims to social assistance by mobile Union citizens within the host Member State. Some believe that justice requires full and equal access of such benefits for all EU citizens, while others think that such claims can be denied to those who have never participated in the host Member State's economic life. Not even Neuvonen and de Witte, their common position on Dano notwithstanding, share the same conception of justice. ${ }^{39}$ Moreover, the more persons we bring to bear upon such questions, the greater our disagreements on the constitution of justice within the EU will become.

This is not to say that we should think of the outcomes produced by the case law implementing legislation as just. We can disagree with the substantive decisions taken, which is a valid ground for criticising the legal rule that supports that decision. What we should realise, however, is that the legislature tries to establish justice when it decides to act. That is, as the political theorist Christiano said it,

to say that the legal system establishes justice among persons is not the same as to say that the legal system defines or constitutes justice among persons. To say that the legal system establishes justice is to say that what the legal system does will, for practical purposes, determine what justice demands among persons. We live in societies where there is a lot of disagreement about justice but we must live in accordance with common rules. ... So to say that the legal rules establish justice does not imply that we cannot think that they are unjust. Indeed, much discussion and debate in democratic societies concerns this very question. ${ }^{40}$

It happens regularly that we think the EU legislature is mistaken in its substantive aspirations and that, had we been in charge, we would be living under a better and more just regime. That thought crosses everyone's mind from time to time and it is everyone's right to criticise the choices made and to offer better alternatives. What gets lost, however, once the legislation and implementing case law is said to have contributed to a moral vacuum is that it establishes a particular conception of justice.

It follows that also the EU is affected by, what Waldron termed, 'the circumstances of politics'. ${ }^{41}$ That means, political decision-making is made more complicated by our substantive political disagreements, but at the same time, such decision-making becomes all the more important

\footnotetext{
${ }^{39}$ On my reading of both accounts, de Witte favours equal access to benefits that purport to alleviate human need, while Neuvonen makes the case for virtually full equal treatment.

40 n 41 above, 55.

${ }^{41}$ n 22 above, 101.
} 
because of it. In a world we inhabit with, and in which our actions have consequences for others, there must be shared rules that guide our behaviour and describe the distribution of resources. Would there be a shared understanding of justice and of the kind of behaviour that is tolerable, it may be that our societies could function with far fewer rules. Absent agreement on those matters, however, it is necessary at some point to settle on a certain set of policies and to decide on common rules that bind all living under it. Hence, precisely the kind of disagreement that complicates political decision-making also necessitates it. This is no different in the EU. Precisely because a common understanding of the broader ideals of European integration is lacking among the Member States and their citizens and so is, certainly, agreement upon how to best implement these ideals, a political process that decides on the EU's common course of action and decides on a set of shared rules is needed.

If the fact of disagreement complicates policy-making in general, it certainly poses a challenge to instrumentalist accounts of legitimate decision-making within the EU. The claim that the EU has legitimate authority only when it acts in the interest of justice disregards that finding objectively true principles of justice has proven impossible so far and that our inquiries are limited by the burdens of judgment. Political procedures are needed exactly to settle our disagreements and to come to an agreed set of rules and rights. Therefore, a theory of legitimate political decision-making within the EU cannot depend on some conception of justice. To be clear, this is not the same as saying that the substantive content of the political decisions taken is irrelevant, and that there should not be concern for, or debate over their justness and goodness. I argue not that legitimacy must substitute justice, but instead, that we should complement our accounts of justice with a theory of legitimate decision-making within the EU. ${ }^{42}$ Our theories of legitimate political authority within the EU should be more greatly concerned with the intrinsic qualities of different institutional processes.

For these reasons, we should be critical of the position, offered by O'Brien in response to those who invoke the will of the legislature, that 'the veil of non-interference is misleading [because deference] to the legislature does not make EU citizenship ideologically neutral, or immutable, and it does not discharge the duty of moral scrutiny'. ${ }^{43}$ Beyond the fact that moral scrutiny and interference are two very different things, in the sense that one may voice moral objections but nonetheless believe that interference is illegitimate, the suggestion that those advocating for deference do so because that is essential to protect the ideological neutrality of EU citizenship misrepresents the argument of those

\footnotetext{
${ }^{42}$ As noted by Waldron, the 'emphasis on justice as the key topic [for study] is a little one-sided'. Jeremy Waldron, Political Political Theory: Essays on Institutions (Harvard University Press 2016) 4.

${ }^{43}$ n 2 above, 1679-1680.
} 
concerned about instrumentalist approaches to legitimate authority. EU citizenship law as it currently stands embodies a conception of justice and, therefore, is ideologically inspired; and seeing our ideological disagreements, we are mistaken if our theories of legitimate institutions are being made contingent on some preferred ideology.

\section{Institutional fallibility}

The suggestion that decisions taken by the EU legislature are authoritative until the judiciary designs a morally more desirable alternative outcome cannot rest solely on the assumption that it is possible objectively to decide on what constitutes a desirable result. Instead, it must logically assume also that the judicial process offers a more reliable procedure for realising justice. Otherwise, the position that the authority of legislation must be made subject to the judges' conception of the good is difficult to maintain. That is, if not there is reason to think that, comparatively speaking, the legislature's performance is below that of the judiciary, the position that the judiciary is not bound by unjust legislative decisions loses much of its attractiveness.

The fallibility of legislatures is all too easily accepted and no plausible account of this institution will deny that the members of our legislative bodies, even the wisest among them, can have an incorrect understanding of the matter in front of them or may fail to see the full consequences of their acts. While, however, legal scholars regularly emphasize the imperfections associated with representative bodies, there is a tendency to assume that the judicial process offers or can be turned into a relatively 'frictionless' alternative to the legislative process. ${ }^{44}$ This 'nirvana fallacy', the

phenomenon of comparing the actual performance of legislatures with an ideal conception of courts, ${ }^{45}$ occurs within EU law scholarship as well. It has been said that 'a well-functioning institution of judicial review contributes in a very practical way to the attainment of justice by ensuring that correct values, procedures and principles are observed in the process of law creation'. ${ }^{46}$ No institution, however, no matter how well it performs, is able to decide with such a degree of perfection. Beyond our substantive disagreements on justice, we should recognise the fact of institutional fallibility and build our institutional theories from there. Our theories of judicial behaviour should not presume that judicial

\footnotetext{
${ }^{44}$ Komesar (n 35 above) 26. See also, Jeremy Waldron, The Dignity of Legislation (Cambridge University Press 1999). ${ }^{45}$ Adrian Vermeule, Judging under Uncertainty: An Institutional Theory of Legal Interpretation (Harvard University Press 2006) 40; Komesar (n 35 above). See also, Keith E Whittington, 'In Defense of Legislatures' (2000) 28 Political Theory 690.

${ }^{46}$ Dorota Leczykiewicz, "Constitutional Justice” and Judicial Review of EU Legislative Acts' in Dimitry Kochenov, Gráinne De Búrca and Andrew Williams (eds), Europe's Justice Deficit? (Hart Publishing 2015) 98.
} 
institutions perform in accordance with some idealised process. If the literature on EU citizenship is somewhat representative of EU legal scholarship more generally speaking, our institutional accounts frequently neglect this more realistic assumption.

It is tempting to focus on cases such as Dano and Alimanovic individually, highlight the beneficial implications of a departure from the rules for the individual claimants, and claim that the Court ought not to be deferential to the delineation of citizenship rights in legislation. However, those who take the position that the judiciary should be free to disregard legislative decisions it considers objectionable must also accept, as Vermeule has emphasised, that also judicial rule 'produces a package of outcomes, both good and bad'. ${ }^{47}$ For example, the judicial attitude advocated for by opponents of Dano and Alimanovic also gave us Commission v UK, a decision known for disregarding legislative provisions at the expense of EU citizens' social rights. ${ }^{48}$ Even more telling is the expulsion case law, which offers a striking contrast with recent decisions on access to social assistance, and which I will examine in some detail here.

Remember that the social assistance case law has been criticised for its deference to the Citizenship Directive's written rules and for conditioning entitlement to social assistance based on periods of residence within the host state. Rather, the argument goes, the Court should have considered the applicants individual circumstances and have realised an outcome that is proportionate seeing the substantive purposes behind the rule. ${ }^{49}$ That is exactly the approach taken in the expulsion case law, to the dismay of often the very same scholars.

The decision in the Onuekwere case concerned the question of whether terms of imprisonment interrupt the right to permanent residence, conferred to citizens who 'have resided legally for a continuous period of five years in the host Member State'. ${ }^{50}$ This right, Article 16(4) of the Citizenship Directive specifies clearly, 'shall be lost only through absence from the host Member State for a period exceeding two consecutive years'. However, invoking the Directive's recitals, the Court reasoned that the EU legislature 'made the acquisition of the right of permanent residence ... subject to the integration of the citizen of the Union'. ${ }^{51}$ Of course, this is plain wrong, for the right to permanent residence depends solely upon a continuous period of legal residence of five years. A clear difference

\footnotetext{
47 n 49 above, 231.

${ }^{48}$ Case C-308/14 Commission v UK, ECLI:EU:C:2016:436. For an analysis of the different cases on EU citizens' access to social assistance, read Shuibhne (n 23).

${ }^{49}$ Verschueren (n 13 above) 373; O’Brien (n 13 above) 950; Nic Shuibhne (n 18 above).

${ }^{50}$ Article 16(1) of the Citizenship Directive.

${ }^{51}$ n 12 above, para 24.
} 
exists between using periods of residence as a proxy to indicate integration and using integration as a condition for permanent residence status. The implications of this confusion are far-reaching, however, for the Court hold that

[s] uch integration, which is a precondition of the acquisition of the right of permanent residence ... is based not only on territorial and temporal factors but also on qualitative elements ... to such an extent that the undermining of the link of integration between the person concerned and the host Member State justifies the loss of the right of permanent residence even outside the circumstances mentioned in Article 16(4) of Directive $2004 / 38^{52}$

Adding grounds for the termination of permanent residence that are nowhere to be found in Article 16(4) of the Directive, ${ }^{53}$ it no longer is a two-year continuous period of absence from the host Member State only that terminates permanent residence, but also any other qualitative element that demonstrates a lack of integration.

Following this decision subsequently in M.G., the Court eradicated the protection against expulsion offered by Article 28 of the Citizenship Directive to public policy and security offenders. Article 28(1) of the Directive states that Union citizens can be expelled on grounds of public policy and security. Article 28(2), however, creates the first exception to that rule, which applies to those who have enjoyed legal and continuous residence in the host Member State for a period of five years. Such EU citizens enjoy permanent residence status, who cannot be expelled 'except on serious grounds of public policy or public security'. Finally, under Article 28(3) no expulsion measures can be taken against those who have resided in the Member States for the previous 10 years or against minors, 'except if the decision is based on imperative grounds of public security'. Following a specific period of residence in the host Member State, in this instance five or ten years, one has presumptively developed such strong ties with the host Member State that a higher level of protection against expulsion becomes necessary. ${ }^{54}$

\footnotetext{
52 Ibid, para 25 (italics added).

53 See also: Nic Shuibhne (n 18 above) 920.

${ }^{54}$ Recital 24 of Directive 2004/38/EC. See, for this conclusion, also: Case C-145/09 Tsakouridis, Opinion of AG Bot, ECLI:EU:C:2010:322, paras 42-43; Kostakopoulou (n 15 above) 458; Emanuela Pistoia, 'The Unbearable Lightness of a Piecemeal Approach. Moving Public Policy of Public Security Offenders in Europe' (2014) 20 European Public Law 745, 753. That there is a presumption of integration underlying these provisions has been observed also by: Dimitry Kochenov and Benedikt Pirker, 'Deporting the Citizens Within the European Union: A Counter-Intuitive Trend in Case C-348/09, P.I. v Oberbürgermeisterin Der Stadt Remscheid' (2013) 2 Colum. J. Eur. L. 369, 385; Pistoia 759.
} 
The Court, on the other hand, first decided that the ten-year period in Article 28(3) had to be calculated by counting back from the moment the expulsion decision had been adopted and that residence in those years 'must, in principle, be continuous'. ${ }^{55}$ In addition, invoking Onuekwere, it decided custodial sentences to be an indication of a lack of integration, which could interrupt the continuity of residence. ${ }^{56}$ This effectively quashed Article 28(3). That the period of continuous residence is to be counted backwards from the moment the expulsion measures is taken, but that periods of imprisonment interrupt this period, means that only those who have been ordered to leave the country ten years after they have served their sentence can rely on Article 28(3). This simply will not happen, as no Member State will adopt an expulsion measure ten years after the convict was released from prison.

Interestingly, the CJEU did in its expulsion case law exactly what different scholars encouraged it to do in the social assistance case law, that is, the application of the recitals over the written rules and condition rights by individual assessments rather than periods of residence. According to M.G., decisions on expulsion must depend on an overall assessment 'of that person's situation on each occasion at the precise time when the question of expulsion arises'. ${ }^{57}$ This time, however, there were no positive implications for the individual citizen, which explains the negative response in the literature. The point is that those who suggest that the CJEU should refuse to follow legislative rules if these produce undesirable consequences or are unfair to the individual affected by them fail to give sufficient thought to the question of which institution protects us against judicial fallibility. For example, opposing the fact that the Citizenship Directive allows for the expulsion of Union citizens, Kochenov and Belavasau argued that ' $[\mathrm{i}] \mathrm{n}$ in ideal world the Court ... should not be deferential to the legislative outcomes of a democratic process which are harmful or make no sense. ${ }^{58}$ However, that we find this statement in an article that otherwise vilifies the CJEU for having ignored legislative provisions, thereby sacrificing the rights of individual citizens and failing to deliver justice, demonstrates that our world is not an ideal one, in which giving such powers to the Court necessarily is beneficial. At some moment, our disagreements must be resolved and a decision be taken, which is treated as authoritative by others. It may be that the authority we favour as the most legitimate will occasionally decide certain matters wrongly in our view. That paradox is an inevitable feature of

\footnotetext{
55 Case C-400/12 M.G., ECLI:EU:C:2014:9, paras 24-27.

${ }^{56}$ Ibid, paras 31-33.

57 Ibid, para 35.

58 n 15 above.
} 
politics. ${ }^{59}$ We value particular institutions and entrust them to decide our disputes despite all their limitations.

\section{The case for the authority of legislation within the EU}

The previous two sections highlighted the shortcomings of the two assumptions supporting instrumentalist theories of legitimacy that favour the Court circumventing the authority of legislation when necessary to realise justice. This section highlights the values we should associate with legislative decision-making and focuses on two distinct qualities of the EU legislature: political legitimacy and institutional ability.

I argued against content-dependent conceptions of legitimacy and explained the need for theories of legitimate political authority within the EU that are separate from our conceptions of justice. Intuitively one may think that, if we were to embrace a content-independent theory of legitimate EU political institutions, the value of legislative decision-making may appear more evident. After all, such theories tend to take a more positive view of legislatures. ${ }^{60}$ Some EU lawyers, however, have managed to resist this conclusion, by creating an interesting sort of catch-22, the EU legislature cannot escape and which always designates the Court as the most legitimate institution. When confronted with content-independent reasons (process), they argue that because the EU legislature's authority is not grounded in democracy, we cannot conclude that the EU legislature offers a fairer process for resolving our disputes than the judiciary. ${ }^{61}$ When it comes to content-dependent reasons (substance), the assumption is either that the both institutions perform equally well (or poorly), or that the CJEU has an edge here. ${ }^{62}$ Hence, it follows either that both institutions are equally legitimate, meaning that decision-making by one cannot be preferred over the other, or that because content-

\footnotetext{
${ }^{59}$ On that paradox, Jeremy Waldron, 'The Core of the Case Against Judicial Review' (2006) 115 The Yale Law Journal 1246, 1372. See also: Christiano, The Constitution of Equality ( $\mathrm{n} 41$ above) 98.

${ }^{60}$ Waldron, The Dignity of Legislation ( $\mathrm{n} 48$ above); Bellamy ( $\mathrm{n} 36$ above); Christiano, The Constitution of Equality ( $\mathrm{n}$ 41 above).

${ }^{61}$ Floris de Witte, for example, has argued any process within the EU lacks legitimacy: 'A European public order, centred on majoritarian first principles, whether given shape through the EU's legislative process, through an overly strict application of the Charter of Fundamental Rights, or through the Court's case law, lacks legitimacy (which is derived from the institutional capacity for self-expression, mediation and re-iteration)'. N 4 above, 1561. See also, Anthony Arnull, 'Judicial Review in the European Union' in Damian Chalmers and Anthony Arnull (eds), The Oxford Handbook of European Union Law (Oxford University Press 2015) 379-385; Herwig Verschueren, 'The EU Social Security Co-Ordination System' in Philip Syrpis (ed), The Judiciary, the Legislature and the EU Internal Market (Cambridge University Press 2012) 181.

${ }^{62} \mathrm{n} 4$ above, 1554.
} 
dependent reasons speak in favour of the judiciary, it is desirable if the authority of legislation is undermined if the judges think they have a better view of what justice requires.

That argument is subject to two plausible objections. To begin with, if it is at all true that both institutions fall short of essential thresholds of process-based legitimacy equally, it does not follow automatically that decision-making by the judiciary is desirable for outcome-related reasons. This is far from evident seeing the conclusions reached in sections 3 and 4: the facts reasonable disagreement and institutional fallibility. I will leave this objection for what it is, because it does not make the case for legislative authority in the required terms. Far more important, to demonstrate that the EU legislature lacks the democratic legitimacy enjoyed by national legislative fora does not establish that the judiciary is as (il)legitimate, from an content-independent perspective, as the legislature. International organisations, including the EU, may very well not be able to satisfy the democratic standards national liberal democracies satisfy. ${ }^{63}$ However, for international cooperation to be minimally legitimate, decision-making ought to be subject to the control of national representative democratic processes of decision-making. Such a 'fair democratic association of states', as Christiano calls it ${ }^{64}$ offers the most plausible pathway to the legitimisation of the EU. Such an association is reasonably legitimate, if the participating states are constitutional democracies, have voluntarily joined the association, and the decision to join was subject to the approval of highly representative processes of decision-making. In addition, also the association's future course of action must remain under the shared and equal control of domestic representative processes, which the delegation of decisionmaking powers to national representatives enables. ${ }^{65}$ International organisation will enjoy a certain independence, but in terms of the adoption of hard law, the input of all states in the collective decisionmaking procedures should be required. ${ }^{66}$ A legitimate system of decision-making in fair associations of democratic states thus is that which makes decisions subject to control by the states' representatives, which, in turn, are subject to democratic control of representatives elected on the basis of fair electoral processes that treat all citizens publicly as equals. Importantly, this is a content-independent theory of

\footnotetext{
${ }^{63}$ Robert A Dahl, 'Can International Organisations Be Democratic? A Skeptic's View' in lan Shapiro and Casiano Hacker-Cordón (eds), Democracy's Edges (Cambridge University Press 1999); Thomas Christiano, 'Democratic Legitimacy and International Institutions' in Samantha Besson and John Tasioulas (eds), The Philosophy of International Law (Oxford University Press 2010); Philip Pettit, 'Legitimate International Institutions: A NeoRepublican Perspective' in Samantha Besson and John Tasioulas (eds), The Philosophy of International Law (OUP 2010).

${ }^{64}$ Christiano, 'Democratic Legitimacy and International Institutions' (n 66).

${ }^{65}$ R Bellamy, 'A European Republic of Sovereign States: Sovereignty, Republicanism and the European Union' (2016) 16 European Journal of Political Theory 188; Christiano, 'Democratic Legitimacy and International Institutions' (n 66). ${ }^{66}$ Christiano, 'Democratic Legitimacy and International Institutions' (n 66) 123.
} 
decision-making, for it acknowledges that disagreement on outcomes also affects transnational governance.

This ideal is not easily realised in practice. The states forming the organisation may lack the democratic procedures that allow for the fair representation of their citizens' interests and, even if democratic, control of domestic democratic over international institutions is difficult to establish. Decision-making of such institutions is opaque and foreign policy often remains the prerogative of the executive rather than legislature. In addition, power asymmetries between the more and less powerful participating states to the organisation may result in domination and remove decisionmaking from their shared and equal control. ${ }^{67}$ Yet, the EU fulfils many of the criteria necessary for the realisation of a fair association reasonably well. The Treaties have been ratified by domestic representative processes that publicly treat their citizens as equals and the European Council, consisting of the Member States' heads of state or government, defines the EU's broader aims and policy directions. ${ }^{68}$

More important, the EU legislative process reasonably, if still inadequately, guarantees that EU decision-making is subject to the Member States' shared and equal control. ${ }^{69}$ Decision-making by qualified majority, after all, much diminishes the chance that minorities are outvoted on a more or less permanent basis. Because this process seeks for a fair balance between smaller and bigger Member States, ${ }^{70}$ legislative decision-making curbs the power asymmetries that exist between the different Member States. ${ }^{71}$ The legislative process, therefore, enables debate between different groups that may disagree on the ideal outcome, but who need to come together and find solutions to common problems that partly satisfy the interests of many of them. ${ }^{72}$ The EU legislature's institutional setup and framework for decision-making is designed precisely to enable the mediation between different values. ${ }^{73}$ Compromise is needed, not only among the different institutions involved in the process the Council, the European Parliament, and national parliaments - but also within them. The EU's

67 ibid 124-126. See also, Philip Pettit, On the People's Terms: A Republican Theory and Model of Democracy (Cambridge University Press 2012).

${ }^{68}$ Article 15 TEU.

${ }^{69}$ Richard Bellamy, "'An Ever Closer Union Among the Peoples of Europe": Republican Intergovernmentalism and DemoiCratic Representation within the EU' (2013) 35 Journal of European Integration 499.

70 ibid 508.

${ }^{71}$ See also the examples offered by, Mark Dawson and Floris Witte, 'Constitutional Balance in the EU after the EuroCrisis' (2013) 76 The Modern Law Review 817.

72 This is an essential feature of all legislatures: Waldron, The Dignity of Legislation (n 47); Bellamy, Political Constitutionalism: A Republican Defence of the Constitutionality of Democracy (n 35).

${ }^{73}$ Damian Chalmers, 'The Democratic Ambiguity of EU Law-Making and Its Enemies' in Anthony Arnull and Damian Chalmers (eds), The Oxford Handbook of European Union Law (First edition, Oxford University Press 2015). 
decisional rules, the heightened majority requirements, and the search for consensus, are all in one way or another meant to ensure that voice is given to this plurality of perspectives. The process of legislating offers strong safeguards against the domination of the weaker and smaller Member States, their views and votes being essential for the enactment of legislation, and ensures that those affected by EU law will have had a fair say in the process leading to the enactment of the applicable rules. Legitimacy being partly comparative, ${ }^{74}$ the claim that no loss of legitimacy occurs if the judiciary acts without regard to legislation is thus hard to maintain.

Some may worry that if we are to embrace the authority of legislation within the EU we must automatically also oppose the practice of judicial review. While it is true that some authors find the institution of legislation so dignified that they oppose the notion of judicial review of legislation altogether, ${ }^{75}$ alternative theories of political legitimacy place legislation front and centre for the reasons I outlined in the previous section, but leave some room for judicial review. ${ }^{76}$ These theories, however, all tend to reject instrumentalist accounts of political legitimacy as implausible and will recognise our reasonable disagreements on justice and acknowledge the fallibility of all institutions. I will leave open the question of the circumstances under which judicial review is warranted within the EU. My intention is merely to show that grounds of political legitimacy give us weighty reasons for recognising more generally the authority of legislation within the EU.

A second reason supporting the case for the authority of legislation within the EU takes seriously the EU legislature's institutional abilities. The previous section explained that we ought not to contrast the actual performance of one with an idealised account of another institution. However, that each institution is fallible and will err occasionally does not imply that all are able to perform all functions of government equally well. Normally, for example, we think that disputes over the precise consequences of specific legal provisions are to be resolved by the judiciary, if only because the judiciary enjoys a presumption of neutrality and independence from the institution that drew up those rules. ${ }^{77}$ Other political problems, however, are better resolved through the legislative process, simply because there is ample reason to think that that institution can discharge of certain tasks more adequately.

\footnotetext{
${ }^{74}$ Waldron, 'The Core of the Case Against Judicial Review' (n 62) 1389.

${ }^{75}$ Waldron, 'The Core of the Case Against Judicial Review' (n 63 above); Bellamy (n 36 above).

${ }^{76}$ Christiano, The Constitution of Equality ( 41 above); Philip Pettit, On the People's Terms: A Republican Theory and Model of Democracy (Cambridge University Press 2012); Dahl (n 3 above).

77 Martin Shapiro, 'The European Court of Justice: Of Institutions and Democracy.' (1998) 32 Israel Law Review 3, 9; Christiano, The Constitution of Equality (n 41) 257; Jeremy Waldron, 'Separation of Powers in Thought and Practice' (2013) 54 Boston College Law Review 433.
} 
The task of drawing up and deciding the framework of general rules that is binding on all Member States is a complex task, requiring consideration of wide-ranging and often controversial questions of policy and morality, which are subject to substantive disagreement. The EU legislature provides not just a forum where the voices of all those affected by the decision can be heard, but also, it can think through the implications of their decisions and design solutions to common problems at the required level of generality. ${ }^{78}$ It enjoys the time, resources, and institutional capacity to process large quantities of information and evaluate alternative policy resolutions properly. The judiciary, on the other hand, is far less equipped to realise comprehensive reform and consider the broader implications of its decisions. It decides in a piecemeal fashion and its case law usually revolves around the specific circumstances of one or a small group of individuals, while the factual circumstances behind the disputes can be highly idiosyncratic. Because, we can safely assume, the judges tend to concentrate on these circumstances as well as the specific arguments presented by the different parties, the judicial principles provided for are often not drafted with the general good in mind but come mostly from the judges' concern to realise an equitable result in the individual case they decide. Being precedent-setting, however, and governing future situations that come before it and arise within the Member States, they may have all sorts of unforeseen political implications. ${ }^{79}$

One instructive example is Martinez. Sala, in many ways an highly unusual case, but one that explains to a considerable degree why we are debating today of whether social assistance can at all be denied to mobile Union citizen. Mrs Martínez Sala had enjoyed legal residence in Germany for a period of around 25 years, held various jobs and also received social assistance during that period, when a request for a child-raising allowance was denied, on the ground that she did not possess a residence permit when she made the application. ${ }^{80}$ Mrs Martínez Sala's right to remain in Germany was not in question though and secured by the European Convention on Social and Medical Assistance. Furthermore, she received permits in subsequent years, indicating that Germany recogniszed her right to reside legally and to claim benefits. The decision to deny benefits to someone who enjoyed 25 years of legal residence and contributed to the host society through economic participation comes across as extremely arbitrary. The Court, perhaps aspiring to address this wrong, invoked principles of EU

\footnotetext{
${ }^{78}$ Waldron, 'Separation of Powers in Thought and Practice' (n 72 above); Thomas Christiano, 'Democratic Legitimacy and International Institutions' in Samantha Besson and John Tasioulas (eds), The Philosophy of International Law (Oxford University Press 2010) 255-259. For a similar conclusion in the context of the EU, read Damian Chalmers, 'The Democratic Ambiguity of EU Law-Making and Its Enemies' in Anthony Arnull and Damian Chalmers (eds), The Oxford Handbook of European Union Law (First edition, Oxford University Press 2015).

${ }^{79}$ Ekins (n 22 above) 122.

${ }^{80}$ Case C-85/96 Martínez Sala, ECLI:EU:C:1998:217, paras 13-16.
} 
citizenship, but did not confine itself to these peculiar facts and reasoned in general terms. It defined the principle that Union citizens with lawful residence in the host state can invoke the right to nondiscrimination on grounds of nationality if their situation falls within the material scope of EU law, ${ }^{81}$ to which it added in later decisions that all situations involving the exercise of free movement rights constitute such a situation. ${ }^{82}$ As a result, all mobile Union citizens with legal residence in another country acquired a claim to social assistance, while the Member States were simultaneously denied the right to revoke someone's residence status as an automatic consequence of that person's recourse to social assistance. ${ }^{83}$ That is to say, a rather unusual case is largely responsible for those general legal principles that make us, approximately 20 years later, discuss whether the duties of social justice demand the Court to disregard even those few derogations from the principle of non-discrimination that remain in the Citizenship Directive. For example, had the Court decided Dano differently and placed the Member States under the obligation to extend equal treatment to persons with rather minimal social connections with the host state, it is uncertain in which circumstances it would still be permissible for the Member States to deny social assistance. Such a decision, while maybe realising justice in the individual case, certainly could have had broad ramifications for the boundaries of social welfare within the EU. I would argue that it is questionable if such decisions are for European judges to make and it seems unlikely that they are in the position to assess the full implications of their decisions. ${ }^{84}$

The case law also frequently demonstrates a certain unawareness for the fact that national authorities are dealing with much larger number of applicants. For a long period, the Court made eligibility to social assistance subject to an assessment of the applicants' real links with or degree of integration within the host Member State. ${ }^{85}$ Expulsion decisions, we saw in section 4, still primarily centre on convicts' social ties. The thought must have been that the law must be fair to all individuals it addresses, which is reason to reject generalisations and consider the personal circumstances of all individuals properly to see if the Directive's rules apply. That may seem like a commendable approach, but is likely a costly one. For a start, the Court, which is deciding on a case-by-case basis, has the

\footnotetext{
81 Ibid para 63.

82 Case C-184/99 Grzelczyk, ECLI:EU:C:2001:458, para 33.

83 Ibid para 43.

${ }^{84}$ For a similar conclusion, Gareth Davies, 'Migrant Union Citizens and Social Assistance: Trying to Be Reasonable About Self-Sufficiency' College of Europe Research Paper in Law 02/2016.

${ }^{85}$ Case C-224/98 D'Hoop, ECLI:EU:C:2002:432, para 38; Case C-258/04 loannidis, ECLI:EU:C:2005:559, para 30; Case C-367/11 Prete, ECLI:EU:C:2012:668, para 33; Case C-209/03 Bidar, ECLI:EU:C:2005:169, para 57; Case C-158/07 Förster, ECLI:EU:C:2008:630, para 49.
} 
capacity to examine the individual's real links with the host Member State in every case that comes before it, but such a requirement would place unacceptable burdens on national authorities, who are dealing with many more individuals. Such requirements result in far greater administrative costs and legal uncertainty. ${ }^{86}$

Moreover, as I have argued elsewhere in more detail, by requiring an assessment of the individual circumstances of EU citizens each time to decide of whether a legislative rule applies, the Court removes the constraints imposed upon national authorities by legislative rules. ${ }^{87}$ Particularly in a Union that divides decisional authority not just between different EU institutions, but also among the Member States, whose political preferences and institutional capacities are highly diverse, there are benefits to rule-based decision-making. It ensures more uniform results and ensures that EU citizens' legal position is less at the mercy of national administrative and judicial officials. ${ }^{8}$ We should oppose making decisions over whether or not someone is entitled to remain within the host Member State to the full discretion of local law-enforcers. By transforming the legal regime governing the expulsion of Union citizens into a quagmire of individual assessments, the Court not simply created great burdens for the responsible national authorities, but also greatly expanded the scope for the arbitrary and abusive treatment of those facing expulsion. The same, of course, goes for the case law on social assistance. It is tempting to support the Court ignoring general rules when beneficial for the individual claimant fortunate enough to be able to bring a case (as well as other indirect beneficiaries), but in a time of increasing hostility against Union citizens seeking welfare support, the benefits of removing decisional discretion from the Member States by offering them clarity concerning the permissible may very well outweigh the positive result in the individual case.

\section{On the need for more freedom for the EU legislature}

One may accept my argument that on grounds of political legitimacy and institutional ability the authority of legislation deserves wider recognition and still reject the idea that the Court's case law has been problematic. It appears to me that two arguments are available to those who wish to resist my claims. First, EU citizenship scholars could accept my normative premises, but try to counter the conclusions I draw from those by insisting that the Citizenship Directive is a poorly drafted piece of

\footnotetext{
${ }^{86}$ See also, de Witte (n 12 above) 137-138; Michael Blauberger and Susanne K Schmidt, 'Welfare Migration? Free Movement of EU Citizens and Access to Social Benefits' (2014) 1 Research \& Politics 1.

${ }^{87} \mathrm{xxx}$

${ }^{88}$ That argument closely follows Frederick Schauer's account of rule-based decision-making. Schauer (n 22).
} 
legislation and that it is not at all evident what the legislature intended to realise. Hence, my conclusion that the case law disrespects the authority of legislation is too strong. Secondly, EU lawyers more generally could equally accept my arguments of legitimacy and institutional ability, but counteract me by arguing that I ignore the EU's hierarchy of legal sources, which demands that the Court polices the legislature strictly and ensures that its decisions are compatible with the Treaties. I believe that I can accept both claims, but that neither affects my argument. Instead, I will demonstrate in this section, many of the shortcomings of the Citizenship Directive are attributable to our failure to acknowledge the constitutional dimension of legislation and refusal to give the EU legislature the freedom it needs to amend the law consistently.

It is not in dispute that the Treaties bind the different institutions and that legislation is subordinate. However, the hierarchy of legal sources argument is not as solid as its proponents think. Legislative politics does not take place merely inside the sphere of constitutional politics, but extends 'to the very constitution of the political'. ${ }^{89}$ That is to say, the act of legislating concerns deciding the appropriate conception, scope, and consequences of Treaty provisions. No reasons exist for assuming that a judicial decision to extend or constrain EU citizens' free movement rights involves a deeper reflection of Treaty rights than a similar legislative decision. Odd as this may sound, the EU legislature is, as Gareth Davies has said it, a 'co-interpreter' of the Treaties and we need to recognise it as such. ${ }^{90}$ Hence, scholars were right to assert the primacy of the Treaties, but the dilemma of the EU legislature's institutional position in the EU's constellation of governance is not easily resolved by invoking the hierarchy of legal sources. Rather, our answer to these questions, as was emphasised by Phil Syrpis before, depends on one's conception of 'the "proper" relationship between the judiciary and the legislature' and, hence, ${ }^{91}$ our account of political legitimacy within the EU.

Whatever our position on legislation, we should not think, as AG Sharpston has come to argue, that interpreting 'the Treaty in the light of secondary law implies a (dangerous) reversal of the institutional balance for rule-making in the European Union'. ${ }^{92}$ To suggest that there is something dangerous in disallowing the judges to dictate the requirements of Treaty law amounts to a deep and uncorroborated mistrust of forms of non-judicial decision-making, with rather problematic side

\footnotetext{
${ }^{89}$ Bellamy (n 36 above) 25. See also: Gareth Davies, 'Legislative Control of the European Court of Justice' (2014) 51 Common Market Law Review 1579, 1584.

90 Davies, 'Legislative Control of the European Court of Justice' ( $\mathrm{n} 84$ above).

91 Phil Syrpis, 'The Relationship Between Primary and Secondary Law in the EU' (2015) 52 Common Market Law Review 461, 462.

92 Daniel Sarmiento and Eleanor Sharpston, 'European Citizenship and Its Union: Time to Move On?' in Dimitry Kochenov (ed), EU Citizenship and Federalism: The Role of Rights (Cambridge University Press (forthcoming)).
} 
effects as a result. As Richard Ekins has argued, 'the common good will not be well served if the lawmaking body lacks sufficient freedom to change the law as reason demands'. ${ }^{33}$ The domain of EU citizenship demonstrates this all too well. We should expect the legislature to act responsibly and offer sufficient guidance in the decisions that it adopts. The EU Citizenship Directive arguably falls short of those standards at times, but a closer inspection of the drafting process tells us that certain of the shortcomings are directly attributable to the fact that certain individual legislators appear to have thought they had to act as the Court's agent. ${ }^{94}$

In section 2, I argued that Dano and Alimanovic respected the constraints of the Citizenship Directive. That, I believe, is a straightforward conclusion in the case of Alimanovic. It was evident that the applicants had not satisfied the temporal requirements set by the Directive. What is curious about the Directive is that Article 24(2) permits the Member States to deny social assistance during the first three months and to jobseekers and students, but is less explicit about the economically inactive who do not fall within those categories. This was the situation of Ms Dano, who had been resident for a period longer than three months, but had never worked and was not looking for employment either. ${ }^{95}$ Therefore, Article 24(2) was not applicable to her case. ${ }^{96}$ AG Wathelet spelled out perfectly the paradoxical situation that would arise were she entitled to social assistance benefits on that ground:

we would arrive at a situation where a national of a Member State who has exercised his right to freedom of movement as a Union citizen without intending to integrate himself into the labour market of the host Member State would be in a more favourable situation than a national of a Member State who has left his country of origin in order to seek employment in another Member State ${ }^{97}$

Economically inactive Union citizens could claim benefits if they would end their search for employment.

To understand how that paradoxical situation came about, we should begin by the initial proposal for a Citizenship Directive, which foresaw that the Member States were under no obligation to confer social assistance to economically inactive Union citizens, until the moment they had acquired

\footnotetext{
${ }^{93}$ Ekins (n 22 above) 120.

${ }^{94}$ Gareth Davies, 'The European Union Legislature as an Agent of the European Court of Justice: EU Legislature as an Agent of the ECJ' (2016) 54 JCMS: Journal of Common Market Studies 846.

${ }^{95} \mathrm{n} 17$ above, paras 35-39.

96 Ibid paras 65-66.

${ }^{97}$ Case C-133/13 Dano ECLI:EU:C:2014:341, Opinion of AG Wathelet, para 116.
} 
permanent residence status. ${ }^{98}$ During the process of negotiating, the Court started developing its jurisprudence on EU citizenship and decided that EU citizens can invoke the non-discrimination principle in all situations involving the exercise of the right to free movement, meaning that those who had exercised the right to free movement were entitled to equal treatment. ${ }^{99}$ The Court pushed the scope of EU citizenship beyond what the legislature had envisaged in its initial proposal and the latter took the decision to remove the initial derogation for economically inactive Union citizens from the Directive. ${ }^{100}$ Initially, the only remaining derogation to equal treatment remaining was the permission to deny maintenance grants to students, no doubt because such assistance fell, per the case law, outside EU law's scope at that time. ${ }^{101}$ Probably realising that also jobseeker benefits still fell beyond the Treaties' scope, ${ }^{102}$ the Council proposed that Member States could also deny such benefits. ${ }^{103}$ The other institutions accepted that suggestion, but a legal gap emerged as a result. Because while the Directive now allows Member States to deny social assistance to jobseekers who have not engaged in an economic activity of sufficient duration before, it is silent as to the position of the economically inactive who are not searching for employment.

The legislature fell short of what we should expect of it, but that cannot be entirely understood without taking into account dominant theories on the authority of legislation within the EU. Consider the documents published by the European Parliament proposing amendments to the Citizenship Directive then under negotiation. On several occasions, its only justification for an amendment was that the Court had decided a case that way. ${ }^{104}$ Ostensibly, the members of the European Parliament

\footnotetext{
${ }^{98}$ Article 21(2) of the Proposal for a European Parliament and Council Directive on the right of citizens of the Union and their family members to move and reside freely within the territory of the Member States (OJ C270E/150).

${ }^{99} \mathrm{n} 77$ above, paras 31-32.

${ }^{100}$ Amended proposal for a Directive of the European Parliament and of the Council on the right of citizens of the Union and their family members to move and reside freely within the territory of the Member States (presented by the Commission pursuant to Article 250 (2) of the EC-Treaty) /* COM/2003/0199 final - COD 2001/0111.

${ }^{101}$ European Parliament Report of 23 January 2003 on the proposal for European Parliament and Council Directive on the right of citizens of the Union and their family members to move and reside freely within the territory of the Member States - Committee on Citizens' Freedoms and Rights, Justice and Home Affairs (2001/0111(COD)). That these benefits fell outside of the Treaty's scope was decided in Case C-197/86 Brown ECLI:EU:C:1988:323, para 18. Also by the time discussion on the Directive took place, the Court had started to put in doubt whether maintenance grants still were excluded from the Treaty's scope: Grzelczyk (n 74) para 35.

102 Case 316/85 Lebon ECLI:EU:C:1987:302, para 26. This decision was reversed when the drafting process of the Citizenship Directive came to a close in Case C-138/02 Collins, ECLI:EU:C:2004:172.

${ }^{103}$ Common Position (EC) No 6/2004 of 5 December 2003 adopted by the Council, acting in accordance with the procedure referred to in Article 251 of the Treaty establishing the European Community, with a view to adopting a directive of the European Parliament and of the Council on the right of citizens of the Union and their family members to move and reside freely within the territory of the Member States (OJ C54E/12).

${ }^{104}$ European Parliament Report of 23 January 2003 on the proposal for European Parliament and Council Directive on the right of citizens of the Union and their family members to move and reside freely within the territory of the
} 
felt the need to obey the meaning accorded to the Treaties by the Court and saw no need for additional consideration over the desirability of these decisions, or their fit with the larger legislative framework. The consequence of the legislature being (or feeling) bound by prior judicial interpretations of Treaty provisions is that it shifts focus to the individual level and shapes legislation in accordance with legal principles adopted in case-by-case decision-making. For example, it amended the Directive to give effect to the Court's decision that expulsion measures cannot be the 'automatic consequence of [someone] having recourse to the host Member State's social assistance system', ${ }^{105}$ thereby at least creating tension with the provision that conditions lawful residence on the EU citizen not being an unreasonable burden on the social assistance system. ${ }^{106}$ It is questionable if, by simply incorporating such judicial statements, the legislature maintains adequate focus on the general level and seeks to offer adequate guidance to all Member States, which must implement the rules and realise legal outcomes that are in accordance with them. ${ }^{107}$ We expect the EU legislature to deliver acts that are reasonably consistent and offer guidance to lower decision-makers and rightly criticise it when it fails to do so, but that expectation is hard to live up to if we also expect it to always defer to prior case law. Hence, while constitutional limits may not be objectionable per se, 'they should be closely specified and adopted with caution'. ${ }^{108}$ If we want to improve the quality of legislation, we should at least offer the EU legislature sufficient room to act reasonably and responsibly.

\footnotetext{
Member States - Committee on Citizens' Freedoms and Rights, Justice and Home Affairs (2001/0111(COD)).

105 Common Position (EC) No 6/2004 of 5 December 2003 adopted by the Council, acting in accordance with the procedure referred to in Article 251 of the Treaty establishing the European Community, with a view to adopting a directive of the European Parliament and of the Council on the right of citizens of the Union and their family members to move and reside freely within the territory of the Member States amending Regulation (OJ C54/12).

${ }^{106}$ Article 14(1) of Directive 2004/38. This tension is not irresolvable. One could imagine that an individual claim to social assistance is not sufficient proof that one is being an unreasonable burden. It has created a fair amount of confusion though. Alexander Somek, 'Solidarity Decomposed: Being and Time in European Citizenship' (2007) 32 European law Review 787.

107 For a similar conclusion, Davies, 'Migrant Union Citizens and Social Assistance: Trying to Be Reasonable About Self-Sufficiency' (n 79 above).

108 Ekins (n 22 above) 120.
} 